\title{
PENGARUH PENERAPAN MODEL DISCOVERY LEARNING BERBANTUAN MACROMEDIA FLASH MELALUI PENGGUNAAN MEDIA ONLINE TERHADAP PENGUASAAN KONSEP BIOLOGI PERSERTA DIDIK
}

\section{THE EFFECT OF MACROMEDIA FLASH ON MODEL DISCOVERY LEARNING APPLICATION THROUGH ONLINE MEDIA OVER STUDENT'S BIOLOGY CONCEPT MASTERING}

\author{
Husnul Azizaturrizkina*, Mukhlis, dan I Wayan Merta \\ Program Studi Pendidikan Biologi FKIP, Universitas Mataram, Mataram, Indonesia \\ *Email: husnulazizaturrizkina.08@gmail.com
}

Diterima: 9 Maret 2021. Disetujui: 24 Mei 2021. Dipublikasikan: 2 Juni 2021

\begin{abstract}
Abstrak: Kemampuan penguasaan konsep merupakan kemampuan yang sangat penting untuk ditingkatkan. Untuk meningkatkannya kemampuan tersebut pada masa covid-19 salah satu inovasi untuk mencapai kemampuan tersebut adalah dengan model pembelajaran Discovery Learning berbantuan Macromedia Flash melalui penggunaan media online. Model Discovery Learning merupakan model pembelajaran yang memiliki 6 tahapan pembelajaran yang mampu mendukung tercapainya kemampuan penguasaan konsep. Penelitian ini bertujuan untuk mengetahui pengaruh penerapan model Discovery Learning berbantuan Macromedia Flash melalui penggunaan media online terhadap penguasaan konsep biologi perserta didik kelas XI MIA di SMAN 1 Lingsar. Jenis penelitian yang digunakan adalah quasi exsperiment (eksperimen semu) dengan desain pretestposttest nonequivalent control group design. Populasi penelitian adalah seluruh kelas XI MIA yang terdiri dari 4 kelas dengan jumlah 143 perserta didik. Teknik pengambilan sampel dengan teknik purposive sampling. Data dianalisis menggunakan uji-t (Polled Varians). Hasil penelitian menunjukkan bahwa $t_{\text {hitung }}=3,22>t_{\text {tabel }}=1,99$ pada taraf signifikan 5\%. Berdasarkan hasil tersebut dinyatakan bahwa penerapan model pembelajaran Discovery Learning berbantuan Macromedia Flash melalui penggunaan media online berpengaruh signifikan meningkatkan penguasaan konsep perserta didik kelas XI MIA di SMAN 1 Lingsar.
\end{abstract}

Kata kunci: Penguasaan Konsep, Discovery Learning, Macromedia Flash

\begin{abstract}
The capability to understanding the concepts is a critical ability to improve. To increase this capability during the covid-19 pandemic, one of the innovations to achieve this capability is the Discovery Learning model assisted by Macromedia Flash using online media. The Discovery Learning model is a learning model with six learning stages that can support mastery of concepts. This study aims to determine the effect of applying the Discovery Learning model assisted by Macromedia Flash using online media on the mastery of biology concepts for class XI MIA students at SMAN 1 Lingsar. This type of research is a quasi-experiment (quasi-experimental research) with a pretest-posttest nonequivalent control group design. The study population was all class XI MIA, which consisted of 4 classes with a total of 143 students. The sampling technique was the purposive sampling technique. Data were analyzed by using a t-test (Polled Variance). The results showed that $\mathrm{t}_{\text {count }}=3.22>\mathrm{t}_{\mathrm{table}}=1.99$ at the $5 \%$ significant level. Based on these results, it is stated that the application of the Macromedia Flash assisted Discovery Learning model using online media has a significant effect on increasing the mastery of the concept of class XI MIA students at SMAN 1 Lingsar.
\end{abstract}

Keywords: Concept Mastery, Discovery Learning, Macromedia Flash

\section{PENDAHULUAN}

Ilmu pengetahuan dan teknologi (IPTEK) berkembang sangat pesat pada era ini. Hal tersebut berdampak pada berubahnya berbagai aspek kehidupan, baik dari segi eknomi, politik, sosial, budaya, agama maupun pendidikan. Dalam bidang pendidikan, teknologi membawa pengaruh yang positif bagi para pendidik terutama memberikan kemudahan dalam melaksanakaan pembelajaran. Perkembangan teknologi ini dapat mempermudah perserta didik mempelajari segala sesuatu melalui berbagai macam media, seperti bahan cetak, program televisi, gambar, audio dan lain sebagainya [1].

Pelajaran biologi, bagi sebagaian besar perserta didik, masih dianggap sebagai mata pelajaran hafalan. Karakteristik yang melekat dari belajar dengan menghafal tersebut, antara lain belajar berarti menambah sejumlah pengetahuan, mengembangkan kemampuan intelektual, dan belajar adalah hasil bukan proses [1]. Dalam belajar menghafal, perserta didik berusaha menguasai bahan tanpa mengetahui maknanya, berbeda dengan belajar bermakna dimana perserta didik mempelajari suatu bahan ajar dengan berusaha memahami makna atau artinya [2]. Penguasaan konsep biologi perserta didik dapat ditingkatkan dengan mengubah teknik atau cara penyampaian materi oleh guru. Guru yang berkualitas tinggi adalah yang memiliki pengaruh kuat terhadap prestasi [3].

Berdasarkan hasil observasi dengan guru 
biologi SMAN 1 Lingsar yakni I Ketut Eka Susantha, S.Pd., menunjukkan bahwa pembelajaran biologi sudah menggunakan slide dengan aplikasi Power Point. Namun, tampilan silde yang digunakan masih terfokus berisi tulisan materi dengan penyajian beberapa gambar. Perserta didik dituntut untuk memperhatikan setiap slide, membaca tulisan pada slide, melihat gambar dan mendengarkan penjelasan dari guru. Hal ini seringkali membuat perserta didik kurang bersemangat, cepat bosan dan mengantuk dalam mengikuti proses pembelajaran sehingga materi yang disampaikan seringkali tidak dimengerti perserta didik. Berbeda dengan mengajar menggunakan slide yang menampilkan video dengan animasi-animasi menarik, gambar yang bergerak, simulasi dan dilengkapi dengan suara yang dapat memfokskan perhatian perserta didik pada meteri. Model slide seperti ini dapat dihasilkan melalui software Macromedia Flash. Guru pada SMAN 1 Lingsar masih belum menggunakan media yang menarik perhatian perserta didik untuk belajar dengan menguasai konsep biologi tersebut.

Permasalahan ini memerlukan solusi, adapun solusi yaitu penggunaan media dalam proses belajar mengajar dapat membantu kelancaran, efektifitas dan efisien dalam pencapaian tujuan pembelajaran. Media merupakan salah satu komponen yang tidak bisa diabaikan dalam mengembangkan sistem pembelajaran yang sukses. Bahkan penggunaan media pembelajaran dalam proses belajar mengajar memiliki pengaruh dan dampak yang besar terhadap minat dan motivasi siswa [4]. Menurut kerucut pengalaman Edgar Dale [5], siswa yang belajar dengan mengandalkan media berbasis verbal (mendengar) akan memperoleh $20 \%$ pengalaman belajar, sedangkan melalui media visual akan memberikan $30 \%$ pengalaman belajar.

Media tersebut diharapkan mampu mendukung pembelajaran biologi menggunakan model Discovery Learning karena guru mengajak siswa bertanya, melihat/mengamati dan mencari sendiri. Model Discovery Learning yang dipadukan dengan animasi Macromedia Flash dan memiliki beberapa kelebihan yaitu dapat membuat siswa mengembangkan potensi intelektual, mengembangkan motivasi intrinsik, menemukan pengetahuannya sendiri, memecahkan persoalan, mengumpulkan dan menganalisis data sendiri serta ingatan siswa lebih tahan lama sehingga mampu mempengaruhi aktivitas siswa, penguasan konsep dan retensi hasil belajar biologi siswa.

Penelitian ini dilkukan melalui penggunaan media online dikarenakan adanya virus COVID-19 yang melanda Indonesia saat ini berdampak bagi pendidikan. Pada tanggal 24 maret 2020 Menteri Pendidikan dan Kebudayaan Republik Indonesia mengeluarkan Surat Edaran Nomor 4 Tahun 2020 Tentang Pelaksanaan Kebijakan Pendidikan Dalam Masa Darurat Penyebaran COVID, dalam Surat Edaran tersebut dijelaskan bahwa proses belajar dilaksanakan di rumah melalui pembelajaran media online/jarak jauh, dilaksanakan untuk memberikan pengalaman belajar yang bermakna bagi siswa. Pembelajaran ini merupakan inovasi pendidikan untuk menjawab tantangan akan ketersediaan sumber belajar yang variatif.

Berdasarkan urian di atas, maka peneliti tertarik untuk melakukan penelitian dengan judul "Pengaruh Penerapan Model Discovery Learning Berbantuan Macromedia Flash Melalui Penggunaan Media Online Terhadap Penguasaan Konsep Biologi Perserta Didik Kelas XI MIA pada SMAN 1 Lingsar".

\section{METODE PENELITIAN}

Jenis penelitian ini adalah eksperimen dengan pendekatan kuantitatif. Metode eksperimen yang digunakan adalah quasi experiment (eksperimen semu) dengan menerapkan model Discovery Learning berbantuan Macromedia Flash melalui penggunaan media online pada kelas eksperimen dan pembelajaran langsung melalui penggunaan media online pada kelas kontrol. Desain penelitian yang digunakan adalah pretest-posttest nonequivalent control group design, pretest dalam desain penelitian dapat digunakan untuk pengontrolan secara statistika sehingga dapat dilihat pengaruh penerapan model model Discovery Learning berbantuan Macromedia Flash melalui penggunaan media online dan pembelajaran langsung melalui penggunaan media online terhadap capaian skor. Penelitian dilaksanakan di SMAN 1 Lingsar tanggal 13 Oktober-07 November pada semester 1 (ganjil) Tahun Ajaran 2020/2021. Populasi dalam penelitian ini adalah semua siswa kelas XI IPA yang terdiri dari 4 kelas dengan total keseluruhan 143 peserta didik. Teknik pengambilan data menggunakan teknik purposive sampling, kelas XI MIA 1 sebagai kelas eksperimen dan kelas XI MIA 4 sebagai kelas kontrol. Teknik pelaksanaan penelitian menggunakan aplikasi WhatsApp group kelas. Pengumpulan data penguasaan konsep dilakukan dengan menggunakan instrumen tes, berupa tes pilihan ganda. Analisis data penelitian dilakukan dengan uji-t (Polled Varians).

\section{HASIL DAN PEMBAHASAN}

Sebelum dilakukan proses pembelajaran pada materi Sistem Gerak Pada Manusia maka terlebih dahulu dilakukan tes awal (pre-test). Pre-tes ini bertujuan mengetahui kemampuan perserta didik sebelum diberikan perlakuan. Setelah menerapkan model Discovery Laerning berbantuan Macromedia Flash di kelas eksperimen dan model pembelajaran langsung dikelas kontrol, perserta didik diberikan tes akhir (post-test) untuk mengetahui penguasaan konsep perserta didik setelah diberikan perlakuan. Nilai ratarata sebelum diberikan perlakuan dan setelah diberikan perlakuan disajikan pada gambar 4.1 


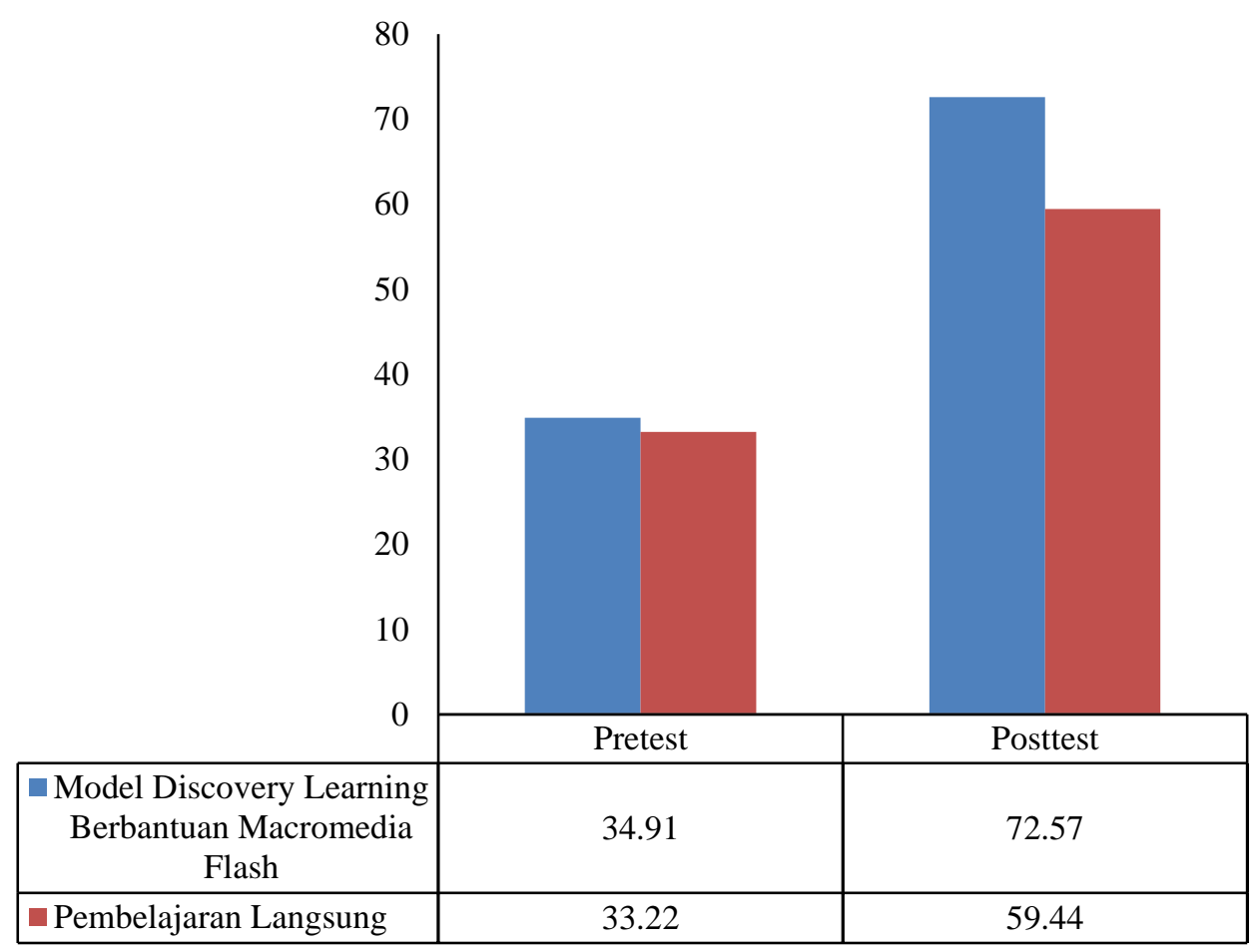

Gambar 1. Nilai Rata-Rata Pre-Test dan Pos-Test Penguasaan Konsep

Berdasarkan data di atas terlihat bahwa sebelum diberilan perlakuan pada kelas yang menerapkan model Discovery Learning berbantuan Macromedia Flash memperoleh nilai 34,91 dan pada kelas yang menerapkan pembelajaran langsung 33,22 (Lampiran13). Selanjutnya setelah diberikan perlakuan pada kelas yang menerapkan model Discovery Learning berbantuan Macromedia Flash memperoleh nilai 72,57 dan pada kelas yang menerapkan pembelajaran langsung 59,44 (Lampiran 12). Berdasarkan data tersebut menunjukkan bahwa terdapat berbedaan yang signifikan terhadap penguasaan konsep setelah menerapkan model Discovery Learning berbantuan Macromedia Flash.

Uji normalitas dalam penelitian ini menggunakan Uji Liliefors. Uji normalitas digunakan untuk mengetahui apakah data berdistribusi normal atau tidak dengan ketentuan data berdistribusi normal bila $L_{\text {hitung }}<L_{\text {tabel }}$ dengan taraf signifikan 0.05. Uji normalitas dihitung dengan menggunakan Microsoft Exsel, diperoleh data seperti pada tabel 1.

Tabel 1 menunjukkan bahwa $L_{\text {hitung }}$ yang diperoleh dari data kelas yang menerapkan model Discovery Learning berbantuan Macromedia Flash dan kelas yang menerapkan pembelajaran langsung lebih kecil dibanding $L_{\text {tabel }}$. Oleh karna itu data tersebut berdistribusi normal. Hal ini berarti kelas yang menerapkan model Discovery Learning berbantuan Macromedia Flash dan kelas yang menerapkan pembelajaran langsung memiliki komposisi perserta didik dengan kemampuan yang hampir sama dalam satu kelas.

Setelah kedua sampel dinyatakan normal, selanjutnya dicari homogenitasinya. Dalam penelitian ini uji yang digunakan yaitu Uji Fisher. Kriteria pengujian yang digunakan yaitu kedua kelas dikatakan homogen jika $F_{\text {hitung }}<F_{\text {tabel }}$. Hasil uji homogenitas dapat dilihat pada tabel 2 .

Hasil analisis statistika seperti yang terlihat pada tabel 2 menunjukkan bahwa kelas yang menerapkan model Discovery Learning berbantuan Macromedia Flash dan kelas yang menerapkan pembelajaran langsung memiliki data yang homogen.

Selanjutnya dilakukan uji beda pre-tes. Uji beda pre-test bertujuan untuk mengetahui kemampuan awal perserta didik sebelum diberikan perlakuan pada kelas yang menerapkan model Discovery Learning berbantuan Macromedia Flash dan kelas yang menerapkan pembelajaran langsung disajikan pada tabel 3.

Hasil anaisis statistika pada tabel 3 menunjukkan bahwa nilai $t_{\text {hitung }}=0,63<t_{\text {tabel }}=1,99$. Ini berarti nilai beda uji pre-test sama atau tidak terdapat perbedaan antara kelas yang menggunakan model Discovery Learning berbantuan Macromedia Flash dan kelas yang menggunakan pembelajaran langsung. 
Tabel 1. Data Uji Normalitas Pre-Test \&Post-Test Kelas Eksperimen \& Kelas Kontrol

\begin{tabular}{ccccc}
\hline \multirow{2}{*}{ Data } & \multicolumn{2}{c}{$\begin{array}{c}\text { Model Discovery Learning } \\
\text { berbantuan Macromedia Flash }\end{array}$} & \multicolumn{3}{c}{ Pembelajaran Langsung } \\
\cline { 2 - 5 } & Pre & Post & Pre & Post \\
\hline Jumlah sampel (N) & 35 & 35 & 36 & 36 \\
Taraf Signifikan & 0,05 & 0,05 & 0,05 & 0,05 \\
$L_{\text {hitung }}$ & 0,14157 & 0,13981 & 0,13666 & 0,12526 \\
$L_{\text {tabel }}$ & 0,14976 & 0,14976 & 0,14767 & 0,14767 \\
Kesimpulan & Data Berdistribusi Normal & Data Berdistribusi Normal
\end{tabular}

Tabel 2. Data Uji Homogenitas Pre-Test \& PosTest Kelas Eksperimen \& Kelas Kontrol

\begin{tabular}{ccccc}
\hline Data & \multicolumn{2}{c}{$\begin{array}{c}\text { Model Discovery Learning } \\
\text { berbantuan Macromedia Flash }\end{array}$} & \multicolumn{2}{c}{ Pembelajaran Langsung } \\
\cline { 2 - 5 } & Pre & Post & Pre & Post \\
\cline { 2 - 5 } & 35 & 35 & 36 & 36 \\
Jumlah Sampel (N) & 0,05 & 0,05 & 0,05 & 0,05 \\
Taraf Signifikan & 130,6689 & 339,8992 & 129,2063 & 249,9683 \\
Varian & \multicolumn{2}{c}{34} & \\
Db pembilang & \multicolumn{2}{c}{35} & 1,0113 & 1,3598 \\
Db penyebut & 1,0113 & 1,3598 & 1,7622 & 1,7622 \\
$F_{\text {hitung }}$ & 1,7622 & 1,7622 & Data Homogen \\
Ftabel & \multicolumn{2}{c}{ Data Homogen } \\
Kesimpulan & \multicolumn{2}{c}{}
\end{tabular}

Tabel 3. Uji Beda Pre-Tes

\begin{tabular}{llccccc}
\hline Model Discovery & Learning & Variabel & df & Taraf kesalahan & $t_{\text {hitung }}$ & $t_{\text {tabel }}$ \\
\cline { 4 - 7 } $\begin{array}{l}\text { Berbantuan Macromedia } \\
\text { \& Pembelajaran Langsung }\end{array}$ & $\begin{array}{c}\text { Penguasaan } \\
\text { konsep }\end{array}$ & 69 & 0,05 & 0,63 & 1,99 \\
\cline { 4 - 7 } & & & & & \\
\end{tabular}

Tabel 4. Hasil Uji Hipotesis

\begin{tabular}{|c|c|c|c|c|c|c|}
\hline \multirow{3}{*}{$\begin{array}{l}\text { Model Discovery Learning } \\
\text { Berbantuan Macromedia Flash \& } \\
\text { Pembelajaran Langsung }\end{array}$} & Variabel & df & $\begin{array}{c}\text { Taraf } \\
\text { kesalahan }\end{array}$ & $t_{\text {hitung }}$ & $t_{\text {tabel }}$ & Kesimpulan \\
\hline & \multirow{2}{*}{$\begin{array}{c}\text { Penguasaan } \\
\text { konsenp }\end{array}$} & \multirow{2}{*}{69} & 0,05 & \multirow{2}{*}{3,22} & 1,99 & \multirow{2}{*}{$\begin{array}{l}\mathrm{H}_{0} \text { ditolak, } \\
\mathrm{H}_{a} \text { diterima }\end{array}$} \\
\hline & & & 0.01 & & 2,65 & \\
\hline
\end{tabular}

Setelah dilakukan uji normalitas, uji homogenitas, dan uji beda pre-test ternyata data pada pada kelas yang menerapkan model Discovery Learning berbantuan Macromedia Flash dan kelas yang menerapkan pembelajaran langsung memenuhi syarat untuk uji hipotesis. Oleh karena itu pengujian hipotesis dilakukan dengan menggunakan uji-t (Polled Varians). Hasil uji hipotesis disajikan pada tabel 3.

Hasil analisis statistik pada tabel 4 menunjukkan bahwa dengan taraf signifikasi 0,05 didapatkan $t_{\text {hitung }}>t_{\text {tabel }}(3.22>1.99)$. Adapun taraf signifikasi 0,01 didaptkan $t_{\text {hitung }}>t_{\text {tabel }}$ (3.22 $>2,65$ ) Sehingga dapat disimpulkan bahwa $\mathrm{H}_{0}$ ditolak, $\mathrm{H}_{\mathrm{a}}$ diterima. Ini berarti terdapat perbedaan yang signifikan antara kelas yang menerapkan model Discovery Learning berbantuan Macromedia Flash dan kelas yang menerapkan pembelajaran langsung. Dengan demikian dapat disimpulkan bahwa penerapan model Discovery Learning berbantuan Macromedia Flash melalui penggunaan media online berpengaruh signifikan meningkatkan penguasaan konsep perserta didik kelas XI MIA di SMAN 1 Lingsar.

Peningkatan pemahaman konsep lebih signifikan meningkat pada kelas yang menerapkan model Discovery Learning berbantuan Macromedia Flash daripada kelas yang menerapkan pembelajaran langsung disebabkan karena pembelajaran dengan menggunakan model Discovery Learning lebih mampu meningkatkan keterampilan penguasan konsep dibandingkan dengan model pembelajaran langsung. Hal ini dikarenakan model pembelajaran langsung yakni model pembelajaran yang lebih berorientasi kepada guru, guru memegang peranan yang dominan dan perserta didik tidak dituntut untuk menemukan materi itu. Ha ini tentunya akan mengakibatkan ketidakbisaan pada perserta didik dalam memperluas dan memperdalam pengetahuannya sehingga perserta didik menjadi pasif. Kurang bermaknya pembelajaran menyebabkan kurang terbentuknya sikap ilmiah pada diri perserta didik [6]. Selain itu juga pembelajaran 
langsung tidak memiliki komponen komponen atau tahap-tahap pembelajaran seperti model Discovery Learning. Tahapan tahapan model Discovery Learning memberikan kesempatan kepada siswa untuk melatih penguasan konsep. Selain itu faktor media juga mendukung pembelajaran. Media yang diciptakan dengan unik dan kreatif mampu memberikan stimulasi yang baik kepada perserta didik untuk lebih bersemangat dalam belajar sehingga dapat mengoptimalkan pembelajaran [7].

Discovery Learning merupakan suatu model pembelajaran yang menuntut peserta didiknya untuk membangun pengetahuan mereka sendiri melalui kegiatan bertukar pendapat, diskusi, membaca dan mencoba [8]. Kelebihan dari model Discovery Learning yaitu dapat melatih perserta didik belajar secara mandiri, melatih kemampuan penalaran perserta didik, serta melibatkan siswa secara aktif dalam kegiatan pembelajaran untuk menemukan sendiri dan memecahkan masalah yang dapat menimbulkan rasa puas yang dapat mendorong perserta didik untuk melakukan penemuan kembali. Model Discovery Learning ini sangat cocok digunakan dikelas guna untuk meningkatakan penguasaan konsep biologi peserta didik sehingga berdampak positif terhadap hasil belajar peserta didik. [9] menyatakan bahwa model Discovery Learning cocok diterapkan di kelas karena model ini berdampak positif terhadap kemampuan berpikir kritis peserta didik. Peserta didik yang memiliki kemampuan berpikir kritis yang baik maka penguasaan konsepnya juga baik.

Penggunaan media yang tepat akan memberikan pengalaman belajar yang tepat kepada siswa, sehingga mereka dapat membangun sendiri pengetahuannya tentang suatu konsep. Semakin konkret media yang digunakan, maka pengalaman yang diperoleh siswa akan semakin tinggi. Flash merupakan software berbasis animasi yang juga dilengkapi teks dan audio. Adanya animasi tersebut sangat efektif dalam membantu siswa memahami konsep-konsep abstrak dalam biologi dan mengatur cara belajarnya, seperti merumuskan strategi belajar, merencanakan aktivitas belajar, mengelola informasi hingga mengevaluasi proses belajarnya. Penggunaan Macromedia Flash diharapkan mampu memberikan dampak yang positif bagi peningkatan penguasaan konsep dan keterampilan metakognitif siswa [10]. Media pembelajaran macromedia flash sangat efektif sebagai sarana untuk menjelaskan materi ajar kepada siswa. Gambar-gambar dan tulisan-tulisan yang dianimasikan dapat mempermudah siswa memahami materi yang diajarkan dan mampu membuat siswa menjadi bergairah untuk belajar [11]. Adapun kelebihan dari media Macromedia Flash membuat tampilan media lebih menarik sehingga dapat membangkitkan motivasi belajar perserta didik dan selain itu juga mempermudah penyampain suatu konsep yang bersifat abstrak khusus materi Biologi.

Model Discovvery Learning berbantuan
Macromedia Flash dapat meningkatkan penguasaan konsep. Konsep merupakan dasar pemahaman dari suatu materi pelajaran. Jika sebuah konsep sudah dikuasai, maka tujuan pembelajaran dapat dikatakan tercapai. Konsep yakni salah satu pengetahuan awal yang harus dimiliki siswa karena konsep merupakan dasar dalam merumuskan prinsip-prinsip. Penguasaan konsep merupakan bagian dari pengetahuan, dimana pengetahuan adalah dimensi pertama dari hasil pendidikan dan kognitif adalah dimensi dari pengetahuan tersebut [12]. Penguasaan konsep adalah kemampuan untuk memahami dan menguasai suatu konsep sehingga mampu memecahkan masalah, memberikan interprestasi dan mengapikasikanya pada kejadian tertentu.

Hasil uji hipotesis menunjukkan bahwa $t_{\text {hitung }}>t_{\text {tabel }}(3.22>1.99)$ sehingga $\mathrm{H}_{0}$ ditolak, $\mathrm{H}_{\mathrm{a}}$ diterima. Ini berarti terdapat perbedaan yang signifikan antara kelas yang menerapkan model Discovery Learning barbantuan Macromedia Flash dengan kelas yang menerapkan pembelajaran langsung. Dengan demikian dapat disimpulkan bahwa penerapan model pembelajaran Discovery Learning berbantuan Macromedia Flash melalui penggunaan media online berpengaruh signifikan meningkatkan penguasaan konsep perserta didik kelas XI MIA di SMAN 1 Lingsar. Hasil ini sesuai dengan hasil penelitan sebelumnya, [13] \& [14]. melaporkan bahwa penggunaan Macromedia Flash 8.0 dapat meningkatkan hasil belajar IPA siswa SD kabupaten Semarang tahun ajaran 2011/2012. [15] mengkombinasikan penggunaan model pembelajaran Berbasis Masalah menggunakan Software Macromedia Flash 8 memperoleh hasil bahwa terjadi peningkatan hasil belajar pada mata pelajaran instalasi penerangan listrikm peserta didik di kelas XI TIPTL SMK Negeri 1 Nganjuk. Hasil penelitian ini didukung pula oleh penelitian yang pernah dilakukan oleh [16] bahwa pengaruh model Discovery Learning berpengaruh terhadap pemahaman konsep IPA dan sikap ilmiah siswa SMP. Hal ini ditunjukkan dengan peningkatan nilai rata-rata pemahaman konsep pada siswa yang diajarkan dengan Discovery Learning lebih tinggi dibandingkan dengan siswa yang diajarkan menggunakan pembelajaran langsung. [17] menyatakan bahwa efektivitas penerapan model Discovery Learning dapat meningkatkan hasil belajar ipa perserta didik VII SMP Negeri 14 Mataram Hal ini sejalan juga dengan hasil penelitian [18] menyatakan bahwa pengaruh model Discovery Learning berbantuan alat praktikum usaha dan energi dapat meningkatkan penguasaan penguasaan konsep perseta didik kelas X MIA di SMAN 1 Gunungsari tahun ajaran 2018/2019

Dengan adanya virus COVID-19 yang melanda Indonesia saat ini menuntut lembaga pendidikan untuk melakukan inovasi dalam proses pembelajaran. Salah satu bentuk inovasi tersebut ialah dengan melakukan pembelajaran secara online atau daring [19]. Sehingga proses pembelajaran dalam 
penelitian ini dilaksanakan secara online atau daring dengan menggunakan bantuan aplikasi WhatsApp group, sebagai usaha untuk menekan penyebaran virus COVID-19 di lingkungan sekolah. Penerapan pembelajaran online memungkinkan peserta didik mengikuti proses pembelajaran dari rumah masingmasing. Mereka dapat mengakses tugas dan mengirim tugas yang diberikan oleh guru tanpa harus datang ke sekolah. Hal ini dapat mengurangi potensi munculnya kerumunan di sekolah. [20] mengemukakan bahwa membatasi perkumpulan massa dapat mengurangi potensi penyebaran Covid-19.

\section{KESIMPULAN}

Berdasarkan hasil penelitian dan analisis data yang telah diurikan pada bab sebelumnya, dapat disimpulkan bahwa penerapan model pembelajaran Discovery Learning berbantuan Macromedia Flash melalui penggunaan media online berpengaruh signifikan meningkatkan penguasaan konsep perserta didik kelas XI MIA di SMAN 1 Lingsar.

\section{DAFTAR PUSTAKA}

[1] Sanjaya, W. 2006. Strategi Pembelajara. Jakarta: Kencana Prebada Media Group.

[2] Sukmadinata, N. S. 2010. Metode Penelitian Pendidikan. Bandung: Remaja Rosdakarya

[3] Sanjaya, W. 2010. Perencanaan \& Desain Sistem Pembelajaran. Jakarta: Kencana Prebada Media Group.

[4] Hadisaputra, S., Hakim, A., Muntari., Hadiprayitno, G., \& Muhlis. 2018. Pelatihan Peningkatan Keterampilan Guru Ipa Sebagai Role Model Abad 21 Dalam Pembelajaran IPA. Jurnal Pendidikan dan Pengabdian Masyarakat, 1(2), 274-277.

[5] Guslinda., \& Kurnia, R. 2018. Media Pembelajaran Anak Usia Dini. Surabaya: Jakad Publishing.

[6] Widiadnyana, I. W., Sadia, I. W., \& Suastra, I.W. (2014). Pengaruh Model Discovery Learning Terhadap Pemahaman Konsep IPA dan Sikap Ilmiah Siswa SMP. Jurnal Program Pascasarjana Universitas Pendidikan Genesha Program Studi IPA, 4(1), 1-13.

[7] Tumurun, S.W., Gusrayani, D., \& Jayadianta A.K. 2016. Pembelajaran Discovery Learning Terhadap Keterampilan Berpikir Kreatif Siswa Pada Materi Sifat-Sifat Cahaya. Jurnal Pena Ilmiah, 1(1), 101-110.

[8] Roestiyah, N. K. 2008. Strategi Belajar Mengajar: Salah Satu UnsurPelaksanaan Strategi Belajar Mengajar: Teknik Penyajian. Jakarta: Rineka Cipta.

[9] Lestari, P., Gunawan \& Kosim. 2019. Model Pembelajaran Discovery dengan Pendekatan Konflik Kognitif Berorientasi pada Kemanpuan Berpikir Kritis Peserta Didik. Jurnal Pendidikan Fisika dan Teknologi, 5(1), 118-123.
[10] Wahyuningsih., Jamaluddin., Karnan. 2015. Penerapan Pembelajaran Biologi Berbasis Macromedia Flash Dan Implikasinya Terhadap Keterampilan Metakognitif Dan Penguasaan Konsep Siswa Kelas VIII SMPN 6 Mataram. Jurnal Pijar MIPA, X (1), 41-46.

[11] Hadiprayitno, G., \& Makhrus, M. (2012). Pengembangan Media Pembelajaran Macromedia Flash Berorientasi Pembelajaran Ipa Terpadu Tipe Connected. Jurnal Pijar MIPA, 7(2), 42-49.

[12] Krathwohl, D. R. (2002). A revision of Bloom's taxonomy: An overview. Theory Into Practice, 41(4), 212-218.

[13] Andriyanto. (2012). Pengaruh Penggunaan Media Pembelajaran Macromedia Flash 8.0 terhadap Hasil Belajar IPASiswa Kelas V di SD Negeri Kebumen 01 Kecamatan Banyubiru Kabupaten Semarang Semester Genap Tahun Ajaran 2011/2012. Salatiga: Universitas Kristen Satya Wancana.

[14] Yusup, M. (2012). Penagruh Penggunaan Media Pembelajaran Macromedia Flash $8.0 m$ terhadap Hasil Belajar IPA Siswa Kelas IV diSD Negeri Watuagung 01 Kecamatan Tuntang Kabupaten Semarang Semester Genap Tahun Ajaran 2011/2012. Salatiga: Universitas Kristen Satya Wancana.

[15]Permana, G., \& Haryudo, S. I. 2015. Pengembangan Model Pembelajaran Berbasis Masalah Menggunakan Software Macromedia Flash 8 Pada Mata Pelajaran Instalasi Penerangan Listrik Untuk Meningkatkan Hasil Belajar Peserta Didik Di Kelas XI TIPTL SMK Negeri 1 Nganjuk. Jurnal Pendidikan Teknik Elektro, 4(3), 1067-1073.

[16] Widiadnyana, I. W., Sadia, I. W., \& Suastra, I.W. (2014). Pengaruh Model Discovery Learning Terhadap Pemahaman Konsep IPA dan Sikap Ilmiah Siswa SMP. Jurnal Program Pascasarjana Universitas Pendidikan Genesha Program Studi IPA, 4(1), 1-13.

[17] Prilliza, M.D., Lestari, N,. Merta, I. W., \& Artayasa. 2019. Efektivitas Penerapan Model Discovery Learning Terhadap Hasil Belajar IPA. Jurnal Pijar MIPA, 15 (2), 130-134.

[18] Turrahmah. M., Susilawati \& Makhrus, M. (2019). Pengaruh Model Discovery Learning Berbantuan Alat Praktikum Usaha Dan Energi Terhadap Penguasaan Konsep Fisika Peserta Didik. Jurnal Pijar MIPA, 14(3), 118-122.

[19] Jamaluddin, D., Ratnasih, T,. Gunawan, H., \& Paujiah, E. (2020). Pembelajaran Daring Masa Pandemik Covid-19 pada Calon Guru: Hambatan, Solusi, dan Proyeksi. Bandung: Lembaga Penelitian dan Pengabdian Kepada Masyarakat UIN Sunan Gunung Djati. 
[20]WHO. (2020). Coronavirus 2019 Technical Guidance Points Of Entry And Mass Gathrings. Diakses dari: https://www.who.int/emergencies/ diseases/novelconavirus2019technical-guidance/ points-of-entryand-mass-gatherings Pada hari Rabu, 26 November 2020. 